\title{
Random thoughts of a (palliative care) surgeon
}

\author{
Prof. Dr Rajesh N Gongal
}

Correspondence: Rector, Patan Academy of Health Sciences

\begin{abstract}
Prof. Dr Rajesh N Gongal,FRCS (Eng) returned to Nepal from UK completing his surgical training in 1998 and has been working in Patan Hospital, initially as a Consultant and then as a Medical Director. Following the establishment of Patan Academy of Health Sciences (PAHS), he was appointed the Founding Dean of School of medicine. At present, he serves as he Rector of PAHS. He also served as the Chief Editor of Journal of Society of Surgeons (JSSN). He initiated Primary Trauma Care (PTC) Training in the country as the Founding Chair of PTC, Nepal. He was the Founding President of Nepal Ambulance Service (NAS), a non- profit initiative as the first proper Emergency Medical Service (EMS) with trained EMTs and a call centre accessed by calling a threedigit number 102. He is the Founding Chairperson of Hospice Nepal, the first palliative care centre in Nepal established in the year 2000. His interest in palliative care led him to Northern Ireland where he worked as fulltime trainee and completed fellowship in palliative care in 2016 under the auspices of Royal College of Physician of Edinburgh. He recently completed MSc in palliative from Ulster University.
\end{abstract}

He has worked as an Instructor for HOPE (Hospital Preparedness for Emergency) Course, 'Primary Trauma Course; and the 'Palliative care' courses. He has presented in numerous national and International conferences and numerous publications in national and nternational journals such as Palliative Medicine and has published handbooks on 'Basic surgical skills' and 'Palliative care' as well.

He is an active member of the Society of surgeons of Nepal and has contributed to its establishment and development in the early days. He also served as the Chief editor of the Journal of Society of Surgeons of Nepal and has played a crucial role in the establishment of the journal encouraging scientific writing and paper publication culture amongst the fraternity. He is an important member of the society and serves as a mentor in the capacity of the advisory board of the journal.

As I walked into Hospice, a sound of music from a harmonium greeted my ears. The music was not perfect -not that I am an expert in the matters of music- but it was soothing to my mind and my soul. It was a young man of 24 with metastatic osteosarcoma in his last few days of life playing on the harmonium. On admission to Hospice several days back, he was very short of breath and had severe chest pain. With some changes to his medications, he was now virtually pain free and not very short of breath. In fact, few days back, during Tihaar, I had seen him playing cards with his friends in the hospice ground and winning some money, a sly smile on his face. Not long after this, he died surrounded by his family and friends.

It has now been seventeen years since we started our journey in the world of palliative care; never have I regretted it. It has helped me become a surgeon in the true sense.
As a surgeon, we live by our knives; we die by our knives. We enjoy the feel of scalpel cutting down on the skin and subcutaneous tissues; we marvel at the beauty of God' artistic acumen as the white areolar tissues gives way to the Metzenbaum, showing us the way around a tumor, and we marvel at our own skills as the tumor gets unravelled from its tentaculoid hold on to the patient's body. Yes, we enjoy all these and so, we should; if we do not enjoy what we do, we cannot excel in our job. But any a times or even, dare I say, most times, our connection with the disease, our connection with our tools goes deeper than our connection with the person who harbors the disease. The theatricals of operation theatres become more important than the ward rounds or the out patients' sessions become a mere fishing ground for more cases. If this be the case, then all we become is an educated technician, a technician nevertheless. To be a true surgeon, we must be able to 
connect with patient and family, to be able to care for them rather than just to treat the disease. To be a cutting surgeon is the easy bit, to be the comforting surgeon is the hard bit.

Paul Kalanithi, a young neurosurgeon suffering from metastatic lung cancer writes in his book 'When breath become Air'

I could hear Emma's (Paul' oncologist) voice again. 'You have to figure out what is most important to you.'

I didn't know. But if I did not know what I wanted, I had learned something, something not found in Hippocrates, Maimonides, or Osler: the physician's duty is not to stave off death or return patient to their old lives but to take into our arms a patient and family whose lives have disintegrated and work until they can stand back up and face, and make sense of, their own existence.

My own hubris as a surgeon stood naked to me now: as much as I focused on my responsibility and power over patients' lives, it was at best a temporary responsibility, a fleeting power.

Emma hadn 't given me back my old identity. She'd protected my ability to forge a new one. And. Finally, I knew I would have to.

Every surgeon should have a palliative care physician within him or her, continuing to care for patients and family beyond the time when the scalpel ceases to have any function for this person. It is my belief that in doing this, it makes our job much more meaningful; it makes our life much more meaningful. 